\section{Yield and Growth of Globe Artichoke under Saline-Sodic Conditions}

\author{
A. Graifenberg, M. Lipucci di Paola, and L. Giustiniani \\ Dipartimento di Biologia delle Piante Agrarie, University degli Studi di Pisa, \\ Viale delle Piagge 23, Piss 56100, Italy
}

\section{O. Temperini}

Istituto di Ortofloroarboricoltura, University degli Studi di Viterbo, Italy

Additional index words. water and soil salinity, crop production, salt tolerance,

Cynara scolymus

\begin{abstract}
Terom' globe artichoke (Cynara scolymus L.) plants were propagated vegetatively and grown for 2 years in soil-filled pots in the greenhouse under saline-sodic conditions. Plants were irrigated with water containing from 1 to $10 \mathrm{~g} \mathrm{NaC1/liter.} \mathrm{Growth}$ and yield responses were evaluated with a two-line response model. The aim of this work was to determine the salt tolerance threshold and slope for artichoke yield and growth expressed in terms of electrical conductivity $(\mathrm{EC})$ of irrigation water $\left(\mathbf{E C}_{\mathrm{i}}\right)$ and saturatedsoil extract $\left(\mathbf{E C}_{\mathrm{e}}\right)$. The thresholds for yield and plant fresh weight (PFW) were the same2.7 and $4.8 \mathrm{dS} \cdot \mathrm{m}^{-1}$ for $\mathrm{EC}_{\mathrm{i}}$ and $\mathrm{EC}_{\mathrm{e}}$, respectively. The slopes for yield-14.4\% and $10.7 \%$ per $\mathbf{d S} \cdot \mathrm{m}^{-1}$ for $\mathbf{E C}_{\mathrm{i}}$, and $\mathrm{EC}_{\mathrm{e}}$-were greater than those for PFW. These data indicate that PFW was less sensitive to soil and water salinity than yield. Plants survived and produced suckers at an $\mathrm{EC}_{\mathrm{e}}$ of $\mathbf{2 1 . 8} \mathrm{dS} \cdot \mathrm{m}^{-1}$, but 'Terom' yield was much more sensitive to saline-sodic conditions.
\end{abstract}

Globe artichoke is grown widely in Mediterranean regions where irrigation water salinity is a serious problem. Although the tolerance of many vegetable crops to water and soil salinity is known (Barbieri and De Pascale, 1992; Maas, 1985, 1986; Maas and Hoffman, 1977), little information is available on the effects of salt on globe artichoke.

During research conducted in the irrigated desert area near Brawley, Calif., Francois et al. (1991) observed that elevated irrigation water salinity reduced the number of marketable artichokes from a seed-propagated cultivar. Salinity also caused severe Ca deficiency in the inner bracts of artichoke buds. Many authors have reported that the most pronounced response of vegetable crops to salt stress is reduced vegetative growth and productivity (Flowers and Yeo, 1989; Shannon, 1984; Sonneveld, 1988; Yadav and Paliwal, 1990).

An investigation was conducted to identify the salt tolerance threshold, in terms of the electrical conductivity (EC) in irrigation water $\left(\mathrm{EC}_{\mathrm{i}}\right)$ and saturated-soil extract $\left(\mathrm{EC}_{\mathrm{e}}\right)$ of globe artichoke, as measuredly yield and plant fresh weight (PFW). Yield response was evaluated with the equation of Maas and Hoffman (1977), who represented the yield response curve for increasing salinity using two intersecting straight lines: a horizontal line with zero slope and a concentration-dependent line whose

Received for publication 5 Oct. 1992. Accepted for publication 11 Mar. 1993. We thank P.J. Stoffella for helpful comments on the manuscript. The work wasfunded by Consiglio Nazionale delle Ricerche, Italy.Th cost of publishing this paper was defrayed inpartbythepayment of page charges. Under postal regulations, this paper therefore must be hereby marked advertisement solely to indicate this fact. slope indicates the yield reduction percentage per unit increase in salinity. The intersection point designates the threshold, i.e., the maximum water or soil salinity that does not reduce yield below that obtained under nonsaline conditions. The relative yield or PFW for any given water or soil salinity exceeding the threshold can be calculated by the equation proposed by Maas and Hoffman (1977): $\mathrm{Y}=100-\mathrm{B}$ (EC-A), where $\mathrm{Y}=$ yield or PFW, $\mathrm{A}=$ salinity threshold, and $\mathrm{B}=$ slope. The experiment was conducted in Viterbo, Italy, during 1989,1990, and 1991 in a greenhouse with roof and side vents opened constantly.

The mean daytime highs and lows in the greenhouse were 23 to $13 \mathrm{C}$ in fall (from Sept. to Nov. 1990) and 11 to $2 \mathrm{C}$ in winter (from Dec. to Feb. 1990-91).

Table 1. Effects of electrical conductivity $(\mathrm{EC})$ of irrigation water $\left(\mathrm{EC}_{\mathrm{i}}\right)$ and saturated-soil extract $\left(\mathrm{EC}_{\mathrm{c}}\right)$ on globe artichoke yield and growth.

\begin{tabular}{|c|c|c|c|c|c|c|}
\hline \multirow{2}{*}{$\begin{array}{l}\text { Irrigation } \\
\text { water } \\
\mathrm{EC}, \\
\left(\mathrm{dS} \cdot \mathrm{m}^{-1}\right)\end{array}$} & \multirow{2}{*}{$\begin{array}{c}\text { Saturated- } \\
\text { soil } \\
\text { extract } \\
\text { EC }_{\mathrm{e}} \\
\left(\mathrm{dS} \cdot \mathrm{m}^{-1}\right)\end{array}$} & \multirow{2}{*}{$\begin{array}{l}\text { Yield/ } \\
\text { plant } \\
(\mathrm{kg})\end{array}$} & \multirow{2}{*}{$\begin{array}{l}\text { Plant } \\
\text { fresh } \\
\text { wt } \\
(\mathrm{kg})\end{array}$} & \multicolumn{2}{|c|}{ Dry wt (g) } & \multirow{2}{*}{$\begin{array}{c}\text { Suckers/ } \\
\text { plant } \\
\text { (no.) }\end{array}$} \\
\hline & & & & Shoot & Root & \\
\hline$\overline{0.74}$ & 2.57 & 1.15 & 11.39 & 1042 & 269 & 23.8 \\
\hline 2.16 & 4.46 & 1.29 & 12.00 & 1054 & 270 & 26.5 \\
\hline 3.63 & 6.90 & 0.84 & 9.35 & 894 & 260 & 11.5 \\
\hline 5.14 & 9.10 & 0.70 & 7.86 & 795 & 260 & 9.8 \\
\hline 6.63 & 11.11 & 0.41 & 5.60 & 572 & 232 & 7.3 \\
\hline 8.08 & 12.21 & 0.15 & 4.61 & 460 & 199 & 5.0 \\
\hline 9.52 & 14.50 & 0.08 & 3.58 & 361 & 157 & 4.3 \\
\hline 10.94 & 17.10 & 0.03 & 2.22 & 192 & 127 & 2.9 \\
\hline 12.35 & 19.90 & 0.03 & 2.02 & 179 & 115 & 2.7 \\
\hline 13.72 & 21.10 & 0.03 & 1.44 & 126 & 92 & 2.1 \\
\hline 15.08 & 21.80 & 0.03 & 0.83 & 77 & 65 & 2.0 \\
\hline Linear & & & & $* *$ & & \\
\hline Quadratic & & $* *$ & * & * & $* *$ & $* *$ \\
\hline
\end{tabular}

${ }_{*, * * *}$ Significant at $P \leq 0.05$ or 0.01 , respectively. Relationship, tested by regression analysis, between EC, levels and responses of each character.
At the appearance of first bud and during harvest, the mean highs and lows were 18 to 7C in Mar. 1991 and 18 to 8C in Apr. and May 1991. Single suckers of 'Terom' globe artichokes were planted in Oct. 1989 into circular plastic pots $(35 \mathrm{~cm}$ in diameter, $40 \mathrm{~cm}$ high) filled with a soil composed of $51 \%$ sand, $16 \%$ loam, and 33\% clay. The $\mathrm{pH}$ was 7.7 and $\mathrm{EC}_{\text {c }}$ was $0.18 \mathrm{dS} \cdot \mathrm{m}^{-1}$.

Salinity treatments were imposed by adding $\mathrm{NaCl}$ at $0,1,2,3,4,5,6,7,8,9$, or 10 g. liter ${ }^{-1}$ to irrigation water containing a $0.5-\mathrm{g}$ soluble fertilizer/liter composed of (by percentage) $20 \mathrm{~N}-8.7 \mathrm{P}-16.6 \mathrm{~K}$. The EC of each solution was measured at $25 \mathrm{C}$ by a digital conductivity meter (model BE 103; Bicasa, Milan, Italy). ECS for 0- to 10-g.liter ${ }^{-1}$ treatments were $0.74,2.16,3.63,5.14,6.63,8.08$, $9.52,10.94,12.35,13.72$, and $15.08 \mathrm{dS} \cdot \mathrm{m}^{-1}$, respectively. When matric potential, indicated by the tensiometer inserted $25 \mathrm{~cm}$ deep, was lower than $-0.80 \mathrm{kPa}$, water was supplied to the plants to achieve $10 \%$ leaching. Irrigation with saline waters started on 10 Oct. 1989 , when suckers were planted. The buds were harvested in the second year between 3 Apr. and 20 May 1991. A randomized completeblock design was used with four plants per treatment, replicated four times with one single plant per pot. Shoot and root dry weights were determined at the end of harvest. Plants were excavated from pots and shaken carefully, and roots were cleaned manually to remove any remaining soil. Living root biomass was dissected from the shoot and PFWS were determined. Shoot and root PFWS were determined after washing and. drying shoots and roots separately in an oven at $70 \mathrm{C}$ for 4 days. Yield represents the total weight of all buds, per plant, that ranged from 35 to $80 \mathrm{~mm}$ in diameter. First-year yield is usually small because plants produce few marketable buds under the Mediterranean climate.

The number of suckers per plant was determined by counting those that emerged during the second growing season (1990-91), when they were 100 to $150 \mathrm{~mm}$ high. $\mathrm{EC}_{\mathrm{e}}$ was determined on five soil samples collected during the second-year growing season. Soil was 
sampled every month from Sept. to Nov. 1990 at the appearance of first bud (Feb. 1991) and at the end of harvest (May 1991). Three soil samples were taken from three plants per treatment. The pots were different for each sampling date; mean $\mathrm{EC}_{\mathrm{e}} \mathrm{s}$ over the year are given in Table 1. Each soil sample was dried and a saturated-soil extract was prepared.

Results were tested by analysis of variance and regression between $\mathrm{EC}_{\mathrm{i}} \mathrm{s}$ and each measured and calculated variable. Linear regression analysis was performed, with relative yield or $\mathrm{PFW}$ expressed as a function of $\mathrm{EC}_{\mathrm{i}}$ or $_{\mathrm{EC}}$.

Yields and shoot and root PFWS of nontreated plants were 1.15 and $11.4 \mathrm{~kg} / \mathrm{plant}$, respectively. Yield, PFW, and shoot dry weight decreased significantly with increased EC, (Table 1). Roots seem to be less affected by salinity than shoots. In the controls and at $15.08 \mathrm{dS} \cdot \mathrm{m}^{-1} \mathrm{EC}_{\mathrm{i}}$, shoot : root ratio changed from 3.9 to 1.2 .

Linear response curves for relative yield and $\mathrm{PFW}$ as a function of $\mathrm{EC}_{\mathrm{i}}$ and $\mathrm{EC}_{\mathrm{e}}$ showed that the thresholds for artichoke yield and PFW were the same: 2.7 and $4.8 \mathrm{dS} \cdot \mathrm{m}^{-1}$ for $\mathrm{EC}_{\mathrm{i}}$ (Fig. 1) and $\mathrm{EC}_{\mathrm{e}}$ (Fig. 2), respectively.

PFW was less sensitive than yield to soil and water salinity; i.e., the yield slope was steeper than the PFW slope (Figs. 1 and 2). Yield was reduced $50 \%$ at an $\mathrm{EC}_{\mathrm{i}}$ of 6.0 $\mathrm{dS} \cdot \mathrm{m}^{-1}$ and at an $\mathrm{EC}_{\mathrm{e}}$ of $9.8 \mathrm{dS} \cdot \mathrm{m}^{-1}$. PFW decreased similarly at $7.3 \mathrm{dS} \cdot \mathrm{m}^{-1}$ for EC, and $11.0 \mathrm{dS} \cdot \mathrm{m}^{-1}$ for $\mathrm{EC}$, . But, at values of $\mathrm{EC}_{\mathrm{i}}>2.7$ $\mathrm{dS} \cdot \mathrm{m}^{-1}$, yield reduction became evident. Francois et al. (1991) reported that the number of marketable artichokes was reduced $\geq 20 \%$ when irrigation water salinity exceeded 2.0 $\mathrm{dS} \cdot \mathrm{m}^{-1}$. They ascribed the decreased production to a severe salinity-induced $\mathrm{Ca}$ deficiency in the inner bracts of artichoke buds. Under our experimental conditions, we observed marginal leaf necrosis and brown areas extending into the interveinal tissue on the old leaves of plants held with $>3.63 \mathrm{dS} \cdot \mathrm{m}^{-1}$ of $\mathrm{EC}_{\mathrm{i}}$ but no visible damage on buds, probably because our irrigation system helped to avoid water stress. Water stress has been responsible for $\mathrm{Ca}$ deficiency in other vegetables also (Bangerth, 1979). The constant and high level of soil humidity maintained in our experiment by controlling soil matric potential at about $-0.80 \mathrm{kPa}$ throughout the growing season permitted a regular distribution of irrigation water. The optimum soil water content and the low temperatures recorded during bud formation avoided disadvantageous changes in plant water status. Consequently, under these environmental conditions, $\mathrm{Ca}$ deficiency did not occur. Also, exchangeable-Ca concentration was high in our soil (5000 ppm).

Globe artichoke plants can survive and produce one or two suckers at an $\mathrm{EC}_{\mathrm{e}}$ of 21.8 $\mathrm{dS} \cdot \mathrm{m}^{-1}$ (Table 1$)$. This value corresponds to 10 $\mathrm{g} \mathrm{NaC1/liter}$ of irrigation water. The salinity threshold for $\mathrm{EC}_{\mathrm{e}}$ in globe artichoke was higher than that of lettuce (Lactuca sativa L.) (1.3 $\mathrm{dS} \cdot \mathrm{m}^{-1}$ ), cabbage (Brassica oleracea $\mathrm{L}$. Capitata Group) (1.8 dS $\left.\cdot \mathrm{m}^{-1}\right)$, spinach (Spinacia oleracea L.) (2.0 dS $\left.\cdot \mathrm{m}^{-1}\right)$, or celery (Apium graveolens $\mathrm{L}).\left(1.8 \mathrm{dS} \cdot \mathrm{m}^{-1}\right)$ (Maas and Hoffman, 1977). Our data indicate that globe

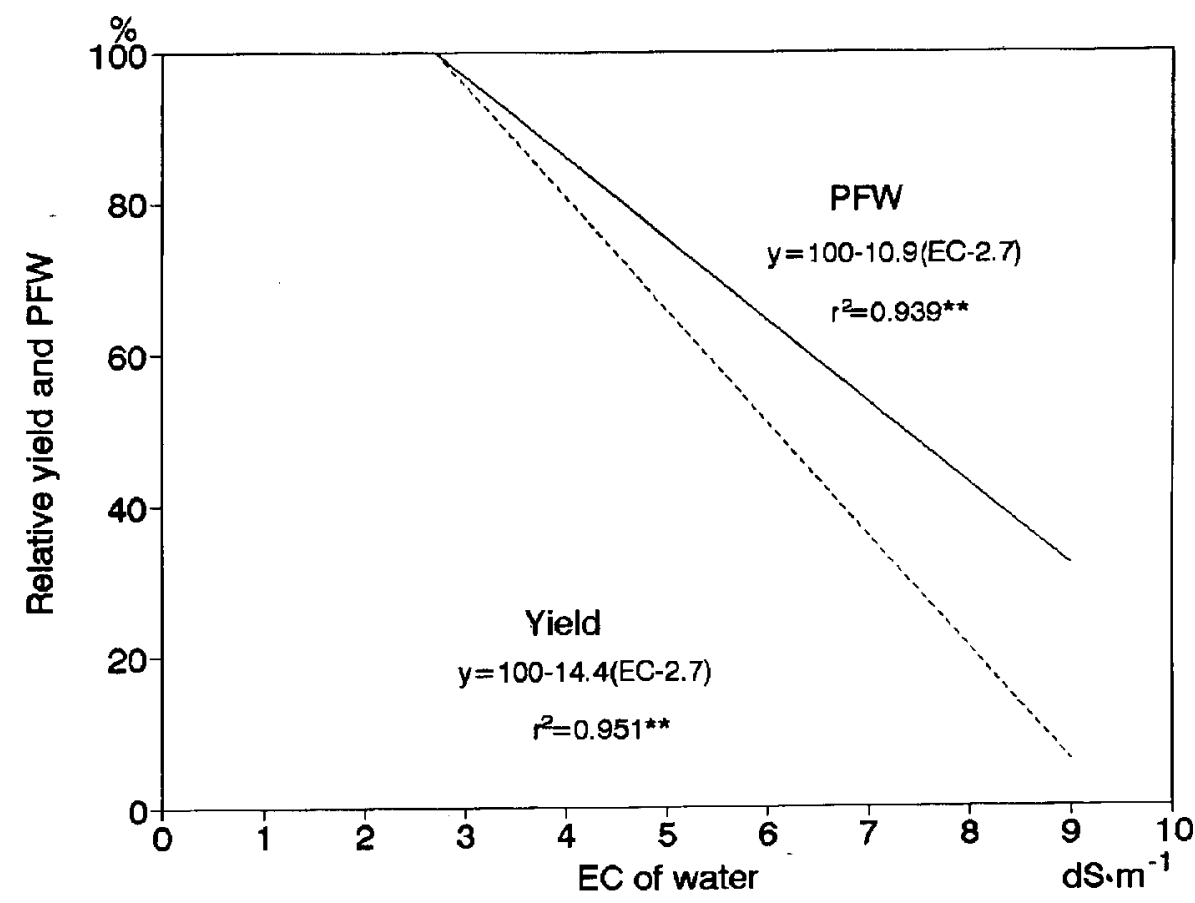

Fig.1.Relationshipbetweenelectrical conductivity (EC) of irrigation water and the relative yield and plant fresh weight (PFW) of globe artichoke.

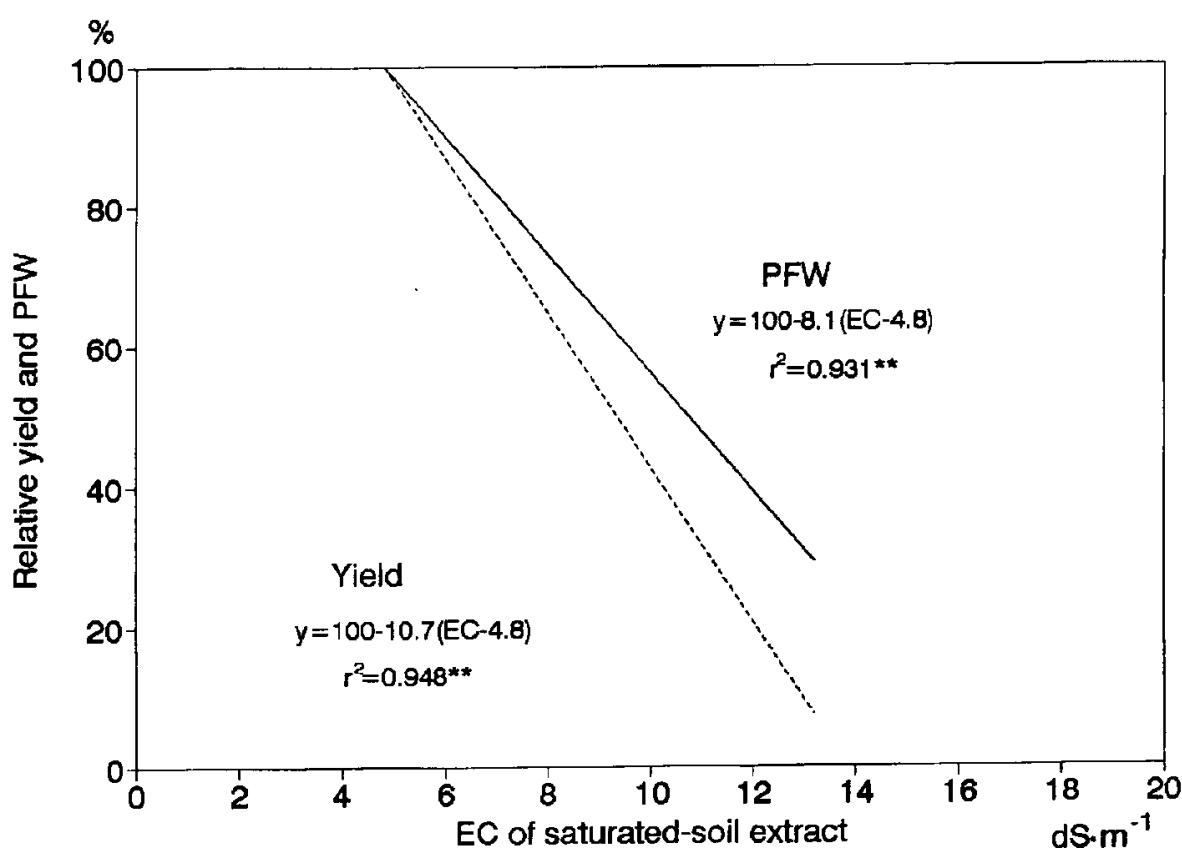

Fig. 2. Relationship between the electrical conductivity (EC) of the saturated-soil extract and the relative yield and plant fresh weight (PFW) of globe artichoke.

artichoke is moderately tolerant to salinity in terms of yield and survival.

Globe artichoke tolerance to saline-sodic conditions is supported by the fact that wild populations of Cynara spp., from which the globe artichoke probably derives, are distributed in coastal areas where soils contain high salt levels (Bozzini and Iachelli, 1976) and by the capacity of this species to accumulate 140 $\mathrm{g}$ Na per kilogram of dry weight in older leaf tissues when it grows under permanent salinesodic conditions (Graifenberg et al., 1992). This salt inclusion mechanism in old vegetative tissues seems to help the plant overcome salt stress effects, because it permits the young leaves to remain at a sublethal salt concentration and maintain active growth and development (Yeo and Flowers, 1984).

\section{Literature Cited}

Bangerth, F. 1979. Calcium related physiological disorders in plants. Annu. Rev. Phytopathol. 17:97-122.

Barbieri, G. and S. De Pascale. 1992. Salinita dell'acquadiirrigazioneecolture ortofloricole. ColtureProtette 2:75-81.

Bozzini, A. and G, Iachelli. 1976. Techniques and 
perspectives of cross and self fertilization in the globe artichoke, p. 695-702. In: Atti 2 Congresso Internazionale sul Carciofo. Edizioni Minerva Medics, Torino, Italy.

Flowers, T.J. and A.R. Yeo. 1989. Effects of salinity on plant growth and crop yields, p. 101-1 19. In: J.H. Cherry (cd.). North Atlantic Treaty Organization Advanced Science Institutes Ser. vol. G19. Environmental stress in plants. SpringerVerlag, Berlin.

Francois, L.E., T.J. Donovan, and E.V. Maas. 1991 Calcium deficiency of artichoke buds in relation to salinity. HortScience 26:549-553.

Graifenberg. A., O. Temperini, L. Giustiniani, L.
Barsanti, and M. Lipucci di Paola. 1992. Compartimentazione del sodio e del potassio in piante di carciofo irrigate con acqua salina. Proc. Giornate Scientifiche Societá Orticola Italiana, Ravello, Italy, 8-10 Apr. 1992. p. 54 55.

Maas, E.V. 1985. Crop tolerance to saline sprinkling water. Plant \& Soil 89:273-289.

Maas, E.V. 1986. Salt tolerance of plants. Applied Agr. Res. 1:12-26.

Maas, E.V. and G.J. Hoffman. 1977. Crop salt tolerance. Current assessment. J. Irr. and Drainage Div. 103:115-134.

Shannon, M.C. 1984. Breeding selection and the genetics of salt tolerance, p. 231-255. In: R.C. Staples and G.H. Toennienssen (eds.). Salinity tolerance in plants: Strategies for crop improvement. Wiley, New York.

Sonneveld, C. 1988. The salt tolerance of greenhouse crops. Neth. J. Agr. Sci. 36:63-73.

Yadav, B.R. and K.V. Paliwal. 1990. Growing vegetables with saline water. Indian Hort. 3:11-13.

Yeo, A.R. and T.J. Flowers. 1984. Mechanism of salinity resistance in rice and their role as physiological criteria in plant breeding, p. 151-170. In: R.C. Staples and G.H. Toemienssen (eds.) Salinity tolerance in plants: Strategies for crop improvement. Wiley, New York. 